\title{
Eurasian snow depth in long-term climate reanalyses
}

\author{
Martin Wegmann ${ }^{1,2,3}$, Yvan Orsolini ${ }^{4}$, Emanuel Dutra ${ }^{5,6}$, Olga Bulygina ${ }^{7}$, Alexander Sterin ${ }^{7}$, and \\ Stefan Brönnimann ${ }^{2,3}$ \\ ${ }^{1}$ Institut des Géosciences de l'Environnement, University of Grenoble, Grenoble, France \\ ${ }^{2}$ Oeschger Centre for Climate Change Research, University of Bern, Bern, Switzerland \\ ${ }^{3}$ Institute of Geography, University of Bern, Bern, Switzerland \\ ${ }^{4}$ NILU - Norwegian Institute for Air Research, Kjeller, Norway \\ ${ }^{5}$ ECMWF - European Centre for Medium-Range Weather Forecasts, Reading, UK \\ ${ }^{6}$ Instituto Dom Luiz, Faculdade de Ciências, Universidade de Lisboa, Lisbon, Portugal \\ ${ }^{7}$ All-Russian Research Institute of Hydrometeorological Information - World Data Centre, Obninsk, Russian Federation
}

Correspondence to: Martin Wegmann (martin.wegmann@univ-grenoble-alpes.fr)

Received: 26 October 2016 - Discussion started: 21 November 2016

Revised: 16 February 2017 - Accepted: 15 March 2017 - Published: 13 April 2017

\begin{abstract}
Snow cover variability has significant effects on local and global climate evolution. By changing surface energy fluxes and hydrological conditions, changes in snow cover can alter atmospheric circulation and lead to remote climate effects. To document such multi-scale climate effects, atmospheric reanalysis and derived products offer the opportunity to analyze snow variability in great detail far back to the early 20th century. So far only little is know about their quality. Comparing snow depth in four long-term reanalysis datasets with Russian in situ snow depth data, we find a moderately high daily correlation (around 0.6-0.7), which is comparable to correlations for the recent era (19812010), and a good representation of sub-decadal variability. However, the representation of pre-1950 inter-decadal snow variability is questionable, since reanalysis products divert towards different base states. Limited availability of independent long-term snow data makes it difficult to assess the exact cause for this bifurcation in snow states, but initial investigations point towards representation of the atmosphere rather than differences in assimilated data or snow schemes. This study demonstrates the ability of long-term reanalysis to reproduce snow variability accordingly.
\end{abstract}

\section{Introduction}

Snow is an important component of the climate system over the mid- and high-latitude regions of the Earth. Its high shortwave albedo and low heat conductivity modulate heat and radiation fluxes at the Earth's surface and thus directly modulates regional temperature evolution and ultimately atmospheric circulation patterns (Barnett et al., 1988; Cohen and Rind, 1991; Callaghan et al., 2011; Cohen et al., 2014). Moreover, because snow acts as a temporary water reservoir, snow variability impacts soil moisture, evaporation and ultimately precipitation processes (Yasunari et al., 1991).

As a result, snow cover has an essential influence on ecological (Jonas et al., 2008; Peñuelas et al., 2009) and economical systems (e.g., Agrawala, 2007). Vice versa, snow cover itself is determined by climate variations. Recent Arctic warming has severely impacted spring snow cover. From 1979 to 2011, Arctic April snow cover extent decreased at a rate of $-17.8 \%$ per decade (Derksen and Brown, 2012). In contrast, regional snow cover increase in autumn over Eurasia was found in connection with low Arctic sea ice concentration (Honda et al., 2009; Wegmann et al., 2015), indicating the complexity of global and regional processes leading to snow cover changes.

Reciprocally, as a corresponding component of the climate system, the snow cover influences large-scale climate patterns and has been tapped as a source of predictability at the subseasonal-to-seasonal scale, especially over Eurasia in au- 
tumn and winter (Cohen and Entekhabi, 1999; Jeong et al., 2013; Orsolini et al., 2013; Wu et al., 2014; Ye et al., 2015,).

Therefore, large-scale monitoring and quantifying of snow cover is crucial for assessing climate change and its representation in climate models (e.g., Frei and Gong, 2005; Brown and Mote, 2009; Brown and Robinson, 2011; Liston and Hiemstra, 2011; Ghatak et al., 2012; Zuo et al., 2015) and for analyzing cryosphere-climate feedbacks (e.g., Flanner et al., 2011; Orsolini and Kvamstø, 2009; Zhang et al., 2013). Here we analyze snow depths in climate reanalyses in comparison to in situ data, with the aim to better assess cryosphere-atmosphere coupling processes in the context of the 20 th century climate evolution.

To this end, reanalysis products provide a compromise between the high temporal resolution and length of in situ observational datasets (e.g., Bulygina et al., 2010) and the large spatial, but relatively short-term, coverage of satellite products (Siljamo and Hyvärinen, 2011; Frei et al., 2012; Hüsler et al., 2014). Comprehensive reanalyses datasets are well suited to investigate processes and mechanisms, and a variety of reanalyses are now routinely produced by meteorological prediction centers such as (but not limited to) NCEP-DOE (National Centers for Environmental Prediction-Department of Energy), ERA-40 (ECMWF Re-Analysis-40) and ERAInterim, and JRA-25 (Japanese reanalysis-25) and JRA-55 (e.g., Uppala et al., 2005; Onogi et al., 2007; Compo et al., 2011; Dee et al., 2011; Rienecker et al., 2011; Poli et al., 2013).

However, so far only a few studies analyzed snow representation in reanalysis products. Khan et al. (2008) compared measured snow data with snow water equivalents and snow depth in the NCEP-DOE (Kanamitsu et al., 2002), ERA-40 (Uppala et al., 2005) and JRA-25 (Onogi et al., 2007) reanalysis products over Russian river basins. They found that the ERA-40 outperformed the NCEP-DOE and JRA25 in terms of correlations and mean values. Despite reproducing well the seasonal variability, all reanalysis products struggled with snowmelt season values. Brown et al. (2010) compared ERA40 and NCEP-NCAR (National Centers for Environmental Prediction-National Center for Atmospheric Research) snow cover extent to satellite and in situ datasets. They found that for the period 1982-2002, ERA-40 shows higher correlations and smaller root mean square errors (RMSEs) than the NCEP reanalysis, and that May values were considerably better approximated than June values. Brun et al. (2013) forced the CROCUS snow model with atmospheric conditions from ERA-Interim (1970-1993) and found very high agreements with Eurasian in situ snow measurements. However, no snow output from the reanalysis was directly evaluated.

In addition, climate reanalyses extending back to the beginning of the 20th century or earlier have now been produced for multi-decadal climate studies. Contrarily to the above-mentioned reanalyses, these climate reanalyses, namely the Twentieth Century Reanalysis version 2 (20CRv2; Compo et al., 2011) and ERA-20C (Poli et al.,
2016), solely rely on assimilation of surface data. Even fewer studies have tried to quantify snow cover extent and depth and their potential impact on climate in such centennial reanalyses. Recently, Peings et al. (2013) compared in situ snow measurements over Russia with 20CRv2 for the whole 20th century and found that it consistently and realistically represents the onset of Eurasian snow cover. However, the authors only investigated the snow dataset in a binary fashion (snow/no snow).

Given the lack of inter-comparison studies of snow depth between reanalyses products, we evaluate snow depth in four centennial state-of-the-art reanalyses. The goal of this study is to assess the consistency between in situ observations and reanalyses estimation of snow depths. To assess this performance, we focus on early snowfall season (October and November) and early snowmelt season (April). This assessment also includes specialized reanalyses for land surface processes, driven by input from the atmosphere.

This article is structured as follows. Section 2 gives an overview of the various datasets analyzed, whereas Sect. 3 defines the methods used in the comparison. Section 4 presents the results for the evaluation. After discussing the results in Sect. 5, conclusions are drawn in Sect. 6.

\section{Data}

In this study, we use six different climate reanalysis datasets, which can be divided into two families, namely the European Centre for Medium-Range Weather Forecasts (ECMWF) products and the NOAA-CIRES Twentieth Century Reanalysis products. These datasets are compared with Russian in situ snow depth measurements.

\subsection{Reanalysis Datasets}

The Twentieth Century Reanalysis version 2 dataset allows retrospective 4-dimensional analysis of climate and weather between 1871 and 2012 (Compo et al., 2011). It was achieved by assimilating synoptic observations of surface pressure into the NCEP GFS (Global Forecast System) model using an Ensemble Kalman Filter variant. Prescribed boundary conditions are HadISST1.1 (Rayner et al., 2003) monthly sea surface temperature (SST) and sea ice cover data as well as forcing of $\mathrm{CO}_{2}$, volcanic aerosols and solar radiation.

The Twentieth Century Reanalysis version 2c (20CRv2c) uses the same model as version 2 with new sea ice boundary conditions from the COBE-SST2 (Centennial ObservationBased Estimates of SST version 2; Hirahara et al., 2014), new pentad Simple Ocean Data Assimilation with sparse input version 2 (SODAsi.2; Giese et al., 2016) sea surface temperature fields, and additional observations from ISPD (International Surface Pressure Databank) version 3.2.9 (Cram et al., 2015). SODAsi.2c is generated by tapering SODAsi.2 at $60^{\circ} \mathrm{N}$ and $\mathrm{S}$ to COBE-SST2 SSTs, which makes the Arc- 
Table 1. Reanalysis product characteristics.

\begin{tabular}{|c|c|c|c|c|c|c|}
\hline Reanalysis & $\begin{array}{l}\text { Assimilated } \\
\text { data }\end{array}$ & $\begin{array}{l}\text { Spatial } \\
\text { resolution }\end{array}$ & $\begin{array}{l}\text { Data assimilation } \\
\text { method }\end{array}$ & Type & $\begin{array}{l}\text { Time } \\
\text { interval }\end{array}$ & $\begin{array}{l}\text { Sea ice } \\
\text { and SST }\end{array}$ \\
\hline ERA-Interim & $\begin{array}{l}\text { Surface, upper air, } \\
\text { satellite }\end{array}$ & $\mathrm{T} 255$ & 4D-Var & Spectral & 1979-present & NCEP prescribed \\
\hline ERA-Interim land & $\begin{array}{l}\text { None, HTESSEL land } \\
\text { model nudged to ERA- } \\
\text { Interim atmosphere }\end{array}$ & $\mathrm{T} 255$ & $\begin{array}{l}\text { None, HTESSEL land } \\
\text { model nudged to ERA- } \\
\text { Interim atmosphere }\end{array}$ & Spectral & 1979-present & \\
\hline ERA-20C & $\begin{array}{l}\text { Surface pressure and } \\
\text { marine surface winds }\end{array}$ & T159 & 4D-var & Spectral & $1900-2010$ & HadISST2 \\
\hline ERA-20C land & $\begin{array}{l}\text { None, HTESSEL land } \\
\text { model nudged to ERA- } \\
\text { 20C atmosphere }\end{array}$ & T159 & $\begin{array}{l}\text { None, HTESSEL land } \\
\text { model nudged to ERA- } \\
20 \mathrm{C} \text { atmosphere }\end{array}$ & Spectral & $1900-2010$ & \\
\hline 20CRv2 & Surface pressure & T62 & $\begin{array}{l}\text { Ensemble Kalman } \\
\text { Filter }\end{array}$ & Spectral & $1871-2012$ & HadISST1.1 \\
\hline $20 \mathrm{CRv} 2 \mathrm{c}$ & Surface pressure & T62 & $\begin{array}{l}\text { Ensemble Kalman } \\
\text { Filter }\end{array}$ & Spectral & $1851-2014$ & COBE-SST2 \\
\hline
\end{tabular}

* Here NCEP refers to changing suite of operational sources from National Centers for Environmental Prediction.

tic sea ice and SSTs consistent. For both products, we use the mean of the 56-member ensemble, at a 6-hourly temporal resolution. The spatial resolution corresponds to a Gaussian T62 grid.

The ERA-20C reanalysis (Poli et al., 2016) uses the Integrated Forecast System (IFS) as a framework to assimilate observations of surface pressure and marine surface winds. It is a global atmospheric reanalysis for the period 1900-2010 with a 3-hourly temporal resolution and a horizontal resolution of T159 with 91 vertical levels, reaching from the surface up to $1 \mathrm{~Pa}$. Sea ice cover and SST forcing come from an ensemble of realizations (HadISST.2.0.0.0), where the variability in these realizations is based on the uncertainties in the observational sources used for this forcing. The radiation scheme follows exactly the Climate Model Intercomparison Project phase 5 proposal, including aerosols, ozone and greenhouse gases (Hersbach et al., 2015).

In addition to the ERA-20C reanalysis, the ERA-20C and ERA-Interim (1979-2015; Dee et al., 2011) land versions (ERA-20C land and ERA-Interim land; Balsamo et al., 2015) are used in our assessment. These land reanalyses consist of offline runs of the ECMWF land surface model, driven by the atmospheric forcing from the respective reanalysis. When calculating the correlation and root mean square error, both the corrected (with GPCP, Global Precipitation Climatology Project) and uncorrected version of ERA-Interim land are used (referred to as ERA-Interim land-d and ERAInterim land-e, respectively). For spatial plots, we only show the corrected version. ERA-20C was analyzed in $0.5^{\circ}$ resolution and ERA-Interim land in $1^{\circ}$ resolution. It is important to note that none of the atmospheric or land reanalyses used in this study assimilated snow measurements. Moreover, all products are available on 6-hourly resolution but were used in daily resolution for comparison with stations.
In ERA-20C, ERA-Interim land-d and ERA-Interim lande snow is represented as an additional layer on top of the upper soil layer, with independent prognostic thermal and mass contents (Dutra et al., 2010). The snow pack is represented by a single layer with an evolution of snow temperature, snow mass, snow density, snow albedo and a diagnostic formulation for the snow liquid water content. The snow mass evolves following a water balance equation coupled to the energy budget via snow phase changes. In 20CRv2 and $20 \mathrm{CRv} 2 \mathrm{c}$ snow is also represented as an independent layer on top of the soil layer with independent prognostic thermal and mass content (Ek et al., 2003; Koren et al., 1999), but there is no account for liquid water content. The parameterizations used for snow density, albedo and fractional coverage are different in the two snow schemes. These constraints might impact the snow depth evolution since there is no constrain by surface data assimilation. However, there are no major differences between the snow models, and their complexity is comparable.

\subsection{Snow depth observations}

This study uses time series of daily snow depths for 820 Russian meteorological stations (distributed as shown in the Supplement Fig. S1). The time series are prepared by RIHMI-WDC (All-Russian Research Institute of Hydrometeorological Information - World Data Centre). Meteorological datasets are automatically checked for quality control. Since the procedure of snow observations changed in the past, particular attention was given to the removal of all possible sources of inhomogeneity in the data. However, there have been no changes in the observation procedures since 1965. Daily observations are measured on three stakes at the weather station, where the average of all three is registered in 
Table 2. Fifteen long-term snow stations taken out of the Russian snow station data pool. Listed are WMO (World Meteorological Organization) ID, name, coordinates, and elevation as well as starting year and missing values. Missing values are indicated relative to the whole sample size of each individual station as average of April, October and November.

\begin{tabular}{|c|c|c|c|c|c|}
\hline WMO ID & $\begin{array}{l}\text { Station } \\
\text { name }\end{array}$ & Coordinates & $\begin{array}{r}\text { Elevation } \\
\text { above sea level }\end{array}$ & $\begin{array}{r}\text { Starting year } \\
\text { if not } 1901\end{array}$ & $\begin{array}{r}\text { Missing values } \\
\text { in } \%\end{array}$ \\
\hline 22550 & Arhangel'sk & $64^{\circ} 30^{\prime} \mathrm{N}, 40^{\circ} 44^{\prime} \mathrm{E}$ & 8 & & 9.6 \\
\hline 23405 & Ust'-Cil'ma & $65^{\circ} 26^{\prime} \mathrm{N}, 52^{\circ} 16^{\prime} \mathrm{E}$ & 78 & 1914 & 6.3 \\
\hline 23711 & Troicko-Pecherskoe & $62^{\circ} 42^{\prime} \mathrm{N}, 56^{\circ} 12^{\prime} \mathrm{E}$ & 135 & & 6.1 \\
\hline 24641 & Viljujsk & $63^{\circ} 47^{\prime} \mathrm{N}, 121^{\circ} 37^{\prime} \mathrm{E}$ & 110 & 1903 & 17.3 \\
\hline 24966 & Ust"-Maja & $60^{\circ} 23^{\prime} \mathrm{N}, 134^{\circ} 27^{\prime} \mathrm{E}$ & 169 & & 16.8 \\
\hline 26063 & St. Petersburg & $59^{\circ} 23^{\prime} \mathrm{N}, 30^{\circ} 18^{\prime} \mathrm{E}$ & 3 & 1902 & 11.3 \\
\hline 27199 & Kirov & $58^{\circ} 36^{\prime} \mathrm{N}, 49^{\circ} 38^{\prime} \mathrm{E}$ & 157 & & 11.7 \\
\hline 27675 & Poreckoe & $55^{\circ} 11^{\prime} \mathrm{N}, 46^{\circ} 20^{\prime} \mathrm{E}$ & 136 & & 17.5 \\
\hline 27955 & Samara (Bezencuk) & $52^{\circ} 59^{\prime} \mathrm{N}, 49^{\circ} 26^{\prime} \mathrm{E}$ & 45 & 1904 & 7.5 \\
\hline 28275 & Tobol'sk & $58^{\circ} 09^{\prime} \mathrm{N}, 68^{\circ} 15^{\prime} \mathrm{E}$ & 49 & 1907 & 19.2 \\
\hline 28440 & Ekaterinburg & $56^{\circ} 50^{\prime} \mathrm{N}, 60^{\circ} 38^{\prime} \mathrm{E}$ & 281 & & 3.8 \\
\hline 30758 & Chita & $52^{\circ} 05^{\prime} \mathrm{N}, 113^{\circ} 29^{\prime} \mathrm{E}$ & 671 & 1926 & 8.9 \\
\hline 32098 & Poronajsk & $49^{\circ} 13^{\prime} \mathrm{N}, 143^{\circ} 06^{\prime} \mathrm{E}$ & 7 & 1908 & 4.5 \\
\hline 35108 & Urals (Kazakhstan) & $51^{\circ} 15^{\prime} \mathrm{N}, 51^{\circ} 17^{\prime} \mathrm{E}$ & 37 & & 25.5 \\
\hline 35121 & Orenburg & $51^{\circ} 41^{\prime} \mathrm{N}, 455^{\circ} 06^{\prime} \mathrm{E}$ & 115 & & 8.8 \\
\hline
\end{tabular}

the time series. When using monthly data, we use the maximum snow depth during that month instead of the mean value, because it reflects the process of snow accumulation (snow depth is a cumulative and highly inertial characteristic of the climate system). It is especially essential for autumn months when the main processes of snow accumulation occurs over the territories of Russia.

\section{Analysis procedure}

\subsection{Choice of long-term daily snow observations}

Out of the over 800 stations, 15 stations were selected with a record extending back to the beginning of the 20th century on a daily basis. Stations with records extending into the 19th century were shortened to start from 1901. All time series end in 2011. Stations with different starting years are indicated in Table 2. Furthermore, Table 2 displays the location of the 15 stations, including the elevation above sea level. To correlate daily measurements with daily reanalysis values, values from the closest grid cell to the station location were chosen. The results therefore include uncertainties concerning the surrounding topography of the stations. Moreover, the relative amount of missing data is shown for the average of all 3 months. As can be seen, data availability differs considerably between months and stations. However, one station (ID 35108) exceeding $20 \%$ missing data in all 3 months was excluded from further analysis. We also excluded one station (ID 32098) for which the related grid box was classified as ocean. This results in a final selection of 13 stations.

\subsection{Calculation of extreme event detection}

To evaluate the detection rate of extreme daily snow depth events, we calculate the 98th percentile values in all reanalysis products in two different ways. Extreme events were calculated for both absolute daily snow depth and accumulated daily snow depth, with the latter being the snow depth difference between 2 consecutive days. The selected dates in the reanalyses are then compared to the station dates. Based on the number of dates selected using station data, a percentage hit rate is calculated, namely the amount of extreme events in station data divided by the amount of correctly selected dates in reanalyses. Snow observations were performed at 08:00 local time, which is different than any of the available reanalysis output. To allow some margin of error, we also perform this hit-rate analysis for $\mathrm{a} \pm 1$ day shift.

\section{Results}

\subsection{Spatial features and magnitude}

While quantitative estimates of how the reanalysis products differ from station data will be shown later, we first show multi-decadal climatology and tendency maps for a more qualitative inspection of the snow representation in reanalyses. Starting with the recent period, Fig. 1 shows the snow depth climatology over 1981-2010 for April, October and November. Unsurprisingly, April displays the overall highest values. Highest snow depths over Eurasia are located in northern Siberia along the $90^{\circ} \mathrm{E}$ meridian. Elevated snow depths are also found over the Russian Far East and over Kamchatka in particular. Both of the features dis- 
played in the station data are also represented by all reanalysis products. Overall, there is a broad agreement in the position of high snow depth areas as well as the snow region boundaries. However, ERA-20C shows notably lower snow depths in northern Siberia, compared to ERA-Interim land and 20CRv2c, but the latter shows generally higher snow depth than station data, especially in April and November.

The decadal tendency in the recent era is shown in Fig. 2, as snow depth anomalies between the 1996-2010 period minus those in the 1981-1995 period. In April, the region with the strongest snow depth decrease is the western, European, part of Russia, west of the Urals and between the Barents and Caspian seas. This feature is clearly underestimated by all reanalyses, best represented by 20CRv2 followed by ERAInterim land. However, the sign of the tendency is not homogenous over the region in the reanalyses, and local snow depth increases can be found. A second region of snow decrease, which is broadly captured by the reanalyses is the Russian Far East, with ERA-20C displaying poorer agreement. A pronounced positive anomaly is found in reanalyses north of Lake Balkhash and extending toward the coasts of the Bara and Laptev seas, though a region where the station coverage is poor. Towards southern Russia, the observed signal is more complex, with snow depth increase towards the border to Kazakhstan, but with snow depth decrease further east on the western side of Lake Baikal, which the gridded products fail to capture, both in terms of extent and magnitude. In autumn, and especially in November, the in situ data reveal a broad longitudinal dipolar pattern with a decrease (increase) of snow depths in the eastern (western) part of Russia reproduced by the reanalyses.

Overall, 20CRv2c captures the observed patterns slightly better than ERA-Interim land, while ERA-20C shows the poorest agreement.

\subsection{Inter-decadal performance}

Figure 3 shows the long-term decadal changes over the northern Russia snowpack (averaging between 50 and $150^{\circ} \mathrm{E}$ and $60-75^{\circ} \mathrm{N}$ ) in the different climate reanalyses, the region of highest snow depths in the selected months. Series of 30-year climatological anomalies were computed with a moving window of 10 years, using the 1981-2010 period as a reference climatology. From the 1941-1970 period onward, all four products show similar tendencies. Further back in time, however, the gridded products diverge: ERA-20C and ERA-20C land continue a downward tendency (mean anomalies decrease) whereas the 20CRv2 and 20CRv2c reanalyses show an overall increase in snow depth, resulting in a notable difference by the early 20th century. This evolution is, despite minor differences, true for all 3 months. For all months, the 20CR family of reanalyses shows strong positive anomalies for the 1911-1940 period, which is the main period of the Early Twenty Century Arctic Warming (ETCAW).
Unfortunately, none of the 13 selected stations with a long record is located in that northern Russia region. A similar behavior emerges, however, if the comparison is made between the 13 stations and the collocated reanalysis data, as shown on Fig. 4. Again, comparing to the 1981-2010 reference climatology disregards differences in snow depth magnitude and helps focusing on long-term tendencies. All 3 months show a divergence of the two reanalysis families towards the beginning of the 20th century. Going backward in time from the recent era, tendencies are similar until the 1941-1970 period but, afterwards, the ECMWF reanalyses show a declining mean snow depth, whereas the 20CR reanalyses favor an increase in snow depth. Interestingly, snow station data agrees very well with the 20CR reanalyses until the 19511980 climate for all 3 months. In comparison, the ECMWF reanalyses show much more pronounced deviations from the station data anomalies. Towards the beginning of the century, the station data agrees more and more with the ECMWF reanalyses in autumn. The ECMWF reanalyses achieve an excellent representation for the 1901-1930 and 1911-1940 periods in autumn (for the 1901-1930 spatial anomalies see Supplement Fig. S2). This, however, is not the case for April, where 20CRv2 data is closest to in situ observations.

\subsection{Sub-decadal and daily performance}

Moving away from decadal tendencies, we now evaluate the daily and the inter-annual snow variability over the 13 selected stations with records extending back to the early days of the 20th century. Figure 5 presents the daily performance between station data and the reanalyses over the recent period (1981-2010).

The melting season (April) generally exhibits the weakest correlation between grid and station, with slightly better values for October and highest values for November. However, this ranking can differ for individual station locations. For the period 1981-2010, the ERA-20C reanalysis achieves better results than the 20CR reanalyses, especially so in April, indicating that melting and temperature evolution is somewhat more accurate in the ECMWF reanalyses. November and, even more so, October correlations are very similar in all four long-term reanalysis products. As to be expected, the ERA-Interim land reanalysis, given the higher quality of atmospheric forcing in the recent era and the finer spatial resolution, generally scores the highest when compared to the respective station with medians above 0.8 in all 3 months. Note that in the correlation analysis, ERA-Interim land-d achieves higher averaged correlation coefficients than the uncorrected version.

Looking at long-term correlations (Fig. 6), the ECMWF reanalyses slightly outperform the 20CR in April, but less so than in the 1981-2010 period. The opposite is now true for October, where the 20CRv2 and 20CRv2c achieve slightly higher averaged correlation coefficient values, whereas in November, all long-term reanalyses have comparable corre- 


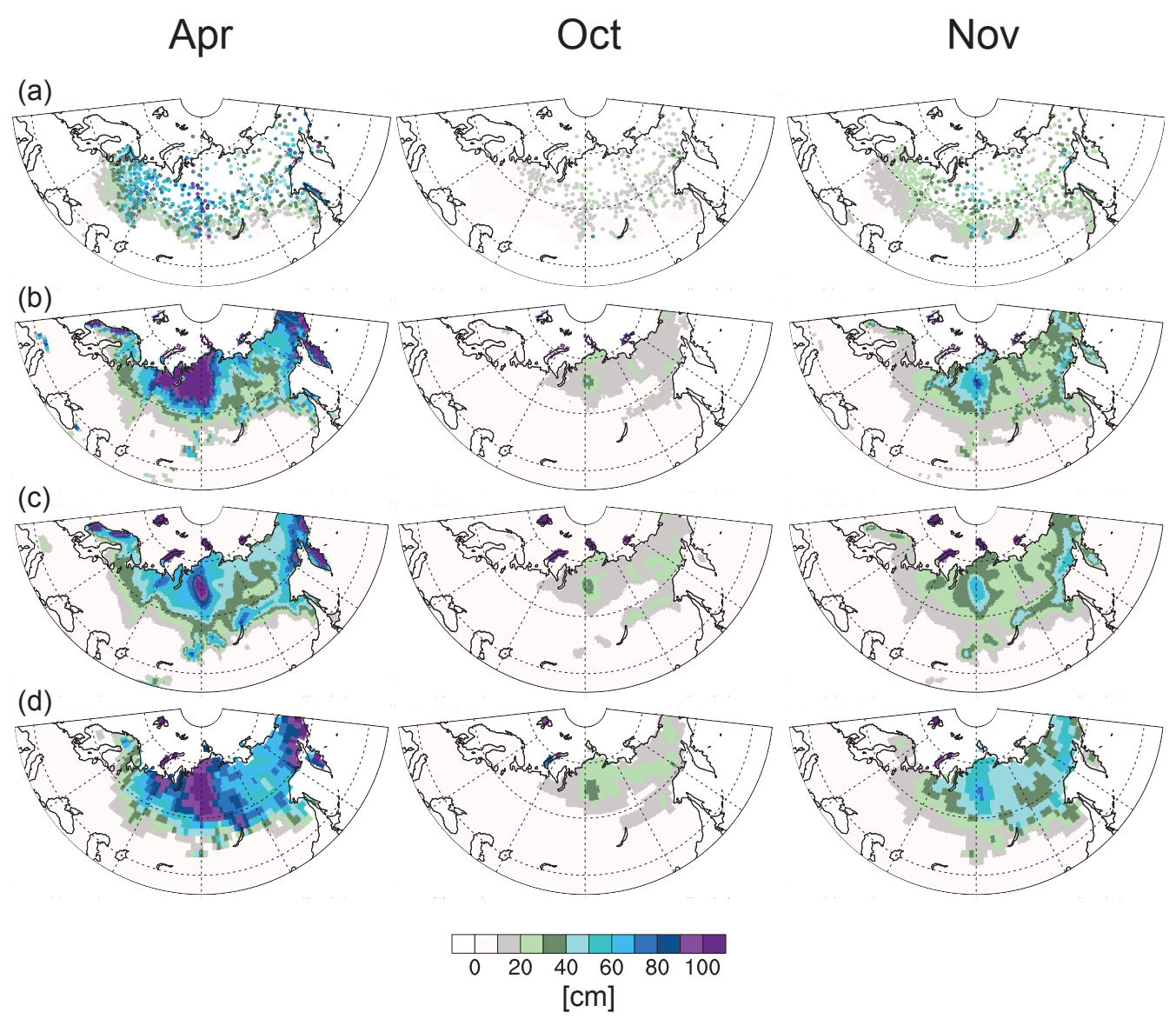

Figure 1. Mean maximum snow depth climatology of (from left to right) April, October and November during the 1981-2010 period in (a) observations, (b) ERA-Interim land-d, (c) ERA-20C and (d) 20CRv2c. ERA-20C land, ERA-Interim land-e and $20 \mathrm{CRv} 2$ are not displayed due to insubstantial differences to ERA-20C, ERA-Interim land-d and 20CRv2c.

lations with station data with slightly higher values for the 20CR family. In 2 out of 3 months, the ERA-20C land version does not realize higher accuracy than the parent product ERA-20C. The same is true for the new 20CRv2c, which outperforms 20CRv2 only in November.

We note that long-term daily correlation coefficients for individual northern stations repeatedly exceed 0.7 (see Supplement Table S1). Only two stations (ID 30758 and ID 35121) consistently show very low correlations across the seasons and reanalyses, probably because of their southern positions. In general terms, the linear correlation performance decreases from northern to more southern stations. This reflects the sensitivity of snowfall in relatively mild environments, resulting in short periods of snow availability. Such small-scale snowfall events are hardly captured by the reanalyses.

Root mean square error values obviously differ from location to location (see Supplement Table S1). Averaging over all stations, reanalyses products were found to produce the absolute largest deviations from the true station time series in April, followed by November and lastly October. The low
October RMSE is influenced by the relatively small absolute snow depth values during that month. Thus, even deviations from zero (e.g., incorrect event of snowfall) will be small. Again, as expected, the ERA-Interim land produces the smallest RMSE over all reanalyses. The ERA-Interim land version without the precipitation correction has a lower RMSE in April and November than the version with the precipitation correction. This could be due to the scarcity and uncertainty of rain-gauge observations in the region, which would deteriorate the GPCP-based correction. The pair of ERA-20C reanalyses clearly outperforms the 20CR pair in April and November but is on equal terms in October.

Finally, to address the variability characteristics of the reanalyzed snow depth values, Figs. 5 and 6 ( $x$ axis) also show the median standard deviation of anomaly time series averaged over the 13 stations. As expected, April and November show much higher variability than October. All ECMWF products show a good representation of the station standard deviation. The uncorrected ERA-Interim land version apparently suppresses a certain amount of variability with lower median values than the rest of the ECMWF family products. 


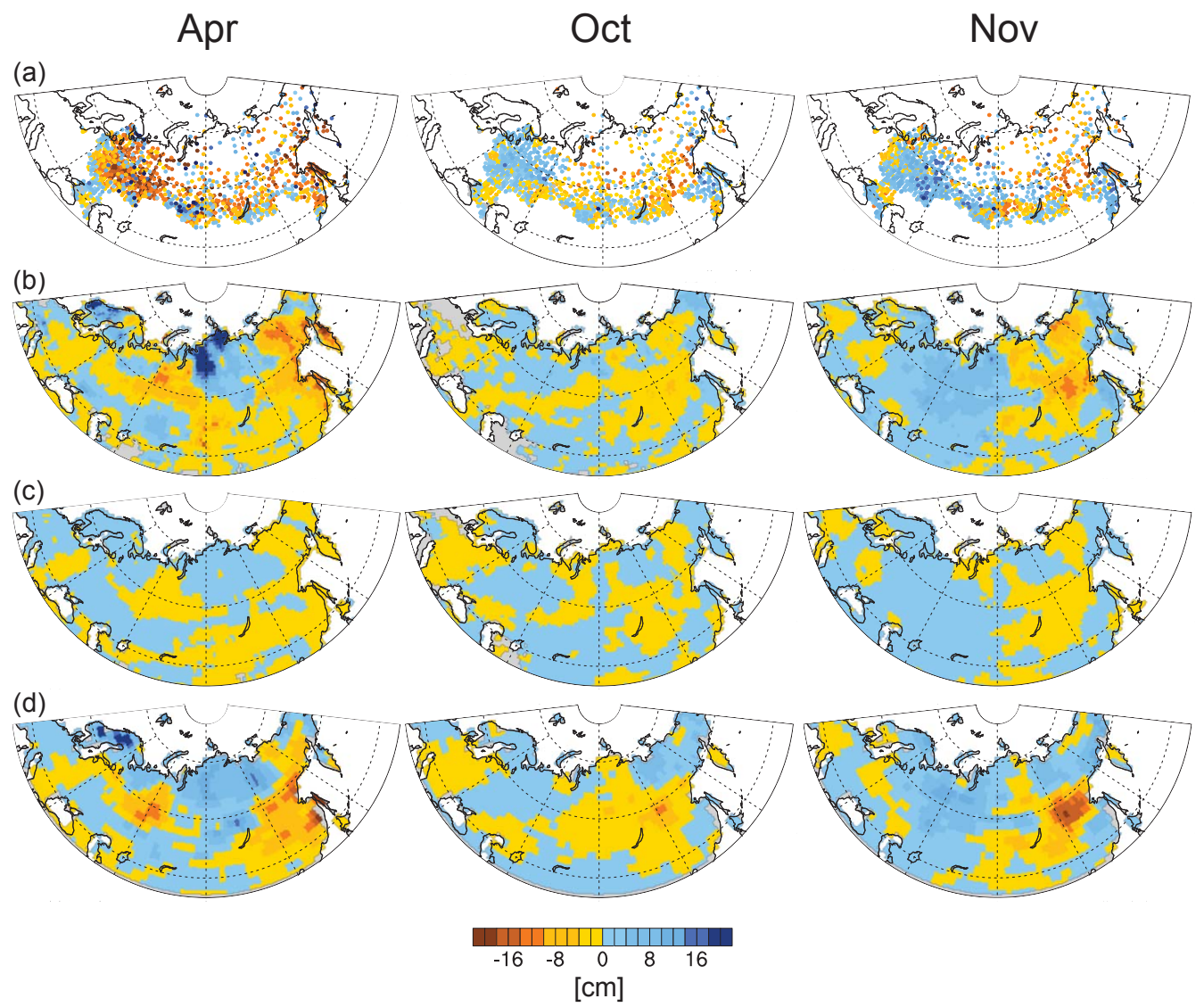

Figure 2. Snow depth anomalies of (from left to right) April, October and November for 1996-2010 minus 1981-1995 in (a) observations, (b) ERA-Interim land-d, (c) ERA-20C and (d) 20CRv2c. ERA-20C land, ERA-Interim land-e and 20CRv2 are not displayed due to insubstantial differences to ERA-20C, ERA-Interim land-d and 20CRv2c.
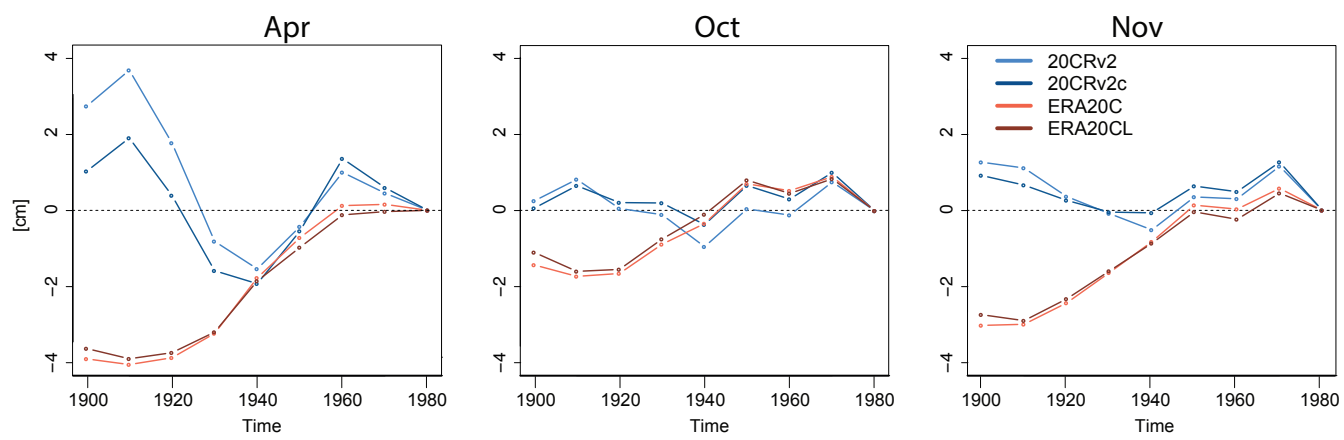

Figure 3. Time series of snow depth anomalies in (from left to right) April, October and November averaged over the main northern Russia snow pack $\left(50-150^{\circ} \mathrm{E}, 60-75^{\circ} \mathrm{N}\right)$. Each data point represents a 30-year-long climatology, starting from 1901-1930 until 1981-2010, with 10 year shifts. Anomalies are calculated relative to the 1981-2010 climatology. ERA-20C is labeled as ERA20C, and ERA-20C land is labeled as ERA20CL.

However, both 20CR reanalyses overestimate the variability. October values for 20CRv2 and 20CRv2c are very much influenced by one outlier location, so that the median is still well within the range of the station median.

Assessment of variability is especially important in the framework of extreme events. Since the replication of vari- ability and daily correlation seems promising, an extreme event hit rate is computed to measure how well the reanalysis products can detect the exact dates of extreme events. Figure $7 \mathrm{a}$ shows the hit rate of days with extreme absolute snow depth values, whereas Fig. 7b shows the hit rate of days with extreme accumulation of snow depth for the 13 station 

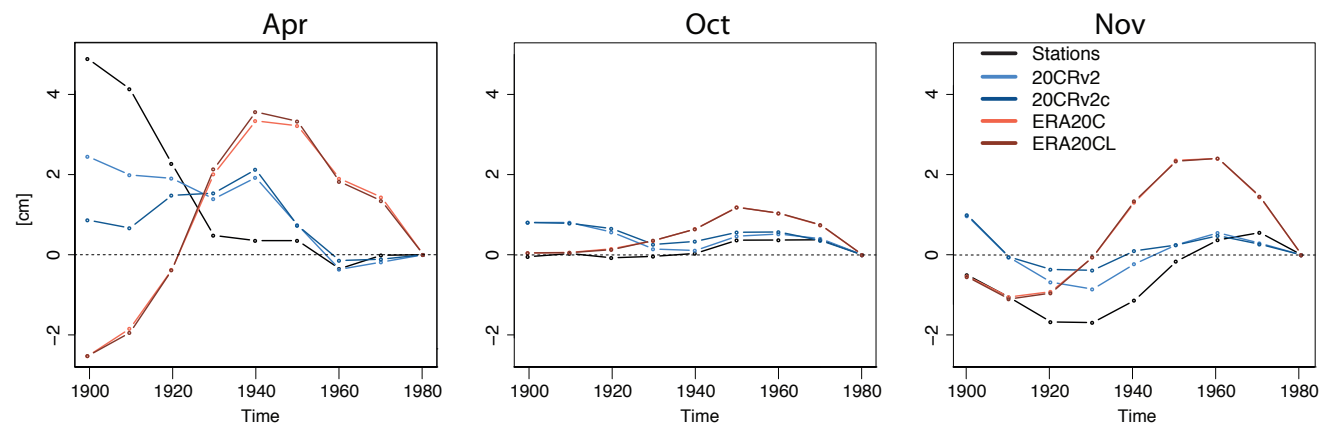

Figure 4. Top: time series of snow depth anomalies in (from left to right) April, October and November for the average of the 13 station locations. Each data point represents a 30-year-long climatology, starting from 1901-1930 until 1981-2010, with 10 year shifts. Anomalies are calculated relative to the 1981-2010 climatology. ERA-20C is labeled as ERA20C, and ERA-20C land is labeled as ERA20CL.

Apr

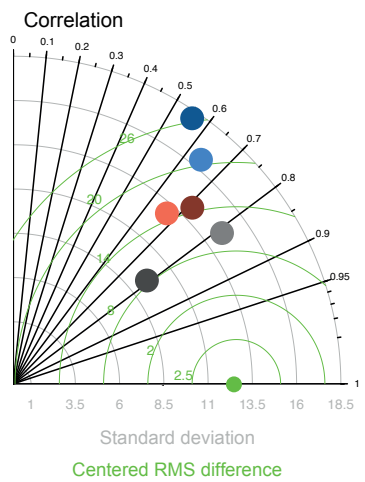

Oct

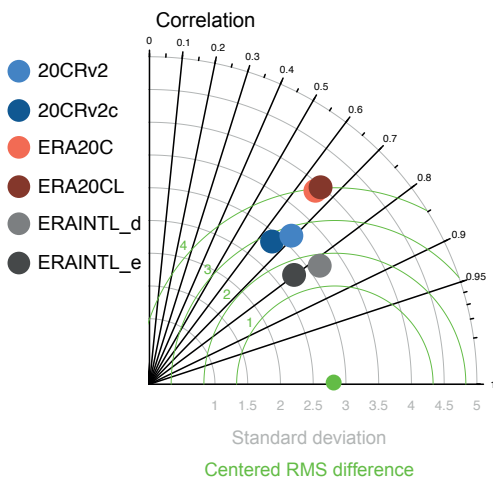

Nov

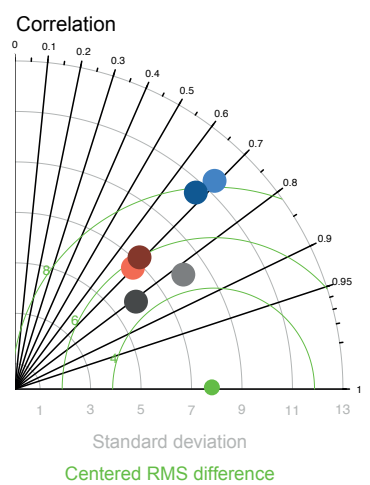

Figure 5. Taylor diagrams showing the median of the 13 station locations using daily data for the period 1981-2010. The $x$ axis and $y$ axis indicate the standard deviation, the radians indicate correlation values and the green circles indicate the centered RMSE. The green dot shows the observed variability. For more details concerning the datasets statistics, see Supplement Figs. S3-S6. ERA-20C is labeled as ERA20C, ERA-20C land is labeled as ERA20CL, ERA-Interim land-d is labeled as ERAINTL_d, and ERA-Interim land-e is labeled as ERAINTL_e.

locations. Since in situ data snow depth and snow depth in reanalyses are not exactly measured at the same time, we allow the reanalysis to be off by \pm 1 day. Better daily correlations in April (Fig. 5) seem to help the ERA-20C reanalyses capture slightly more dates correctly than the two $20 \mathrm{CR}$ products. The opposite is true for autumn months, especially for absolute snow depth maxima. Interestingly, changing from absolute to accumulation extremes helps ERA-20C achieve a higher hit rate, whereas the $20 \mathrm{CR}$ products show a slightly worse hit rate for the latter metric. Moreover, ERA-20C land, which shows a very similar if not better performance for absolute snow depth extremes, shows a slightly poorer performance for detecting accumulation extremes. Overall though, mean hit rates stay well below $50 \%$, and only for single locations did the hit rates exceed this threshold. If we remove the flexibility to be off by 1 day, the amount of correct hits is reduced even further (over all by ca. 10\%, not shown)

\section{Discussion}

Comparing snow depths in multiple long-term, centennial reanalyses with in situ measurements over Russia, our results indicate ambivalent performances of the reanalysis products. Climatologies are well represented spatially but overestimate the mean snow depth in most parts of the analyzed domain. Long-term daily correlations revealed decent coefficient values for most of the station locations. Snow depths from surface input-only reanalyses consistently show linear correlations of 0.6 and higher, although dealing with fluctuating daily data, including rapid changes in weather patterns. Moreover, due to spatial averaging and shortcomings in model topography, relatively low correlation coefficients are expected. Khan et al., 2008 found best case basin-wide correlations of around 0.65 in ERA-40 and JRA-25, with much worse correlations for the NCEP-DOE reanalysis. All these reanalyses assimilated a variety of input data, not only surface data as is the case with the centennial reanalyses ex- 
Apr

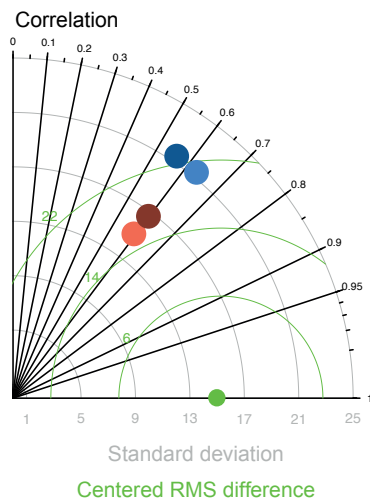

Oct

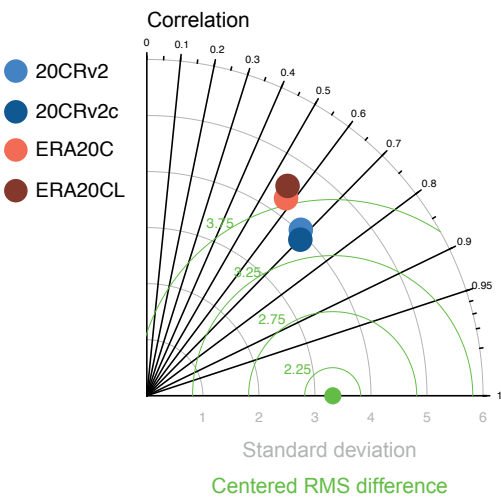

Nov

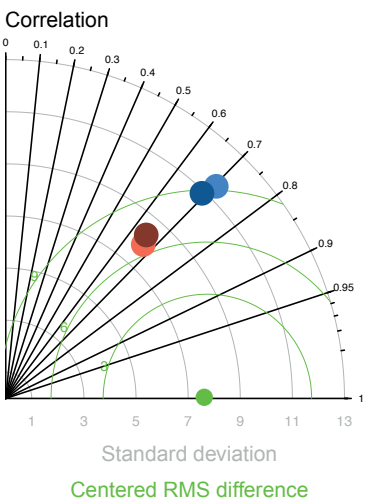

Figure 6. Taylor diagrams showing the median of the 13 station locations using daily data for the longest period available (see Table 1). The $x$ axis and $y$ axis indicate the standard deviation, the radians indicate correlation values and the green circles indicate centered RMSE. The green dot shows the observed variability. For more details concerning the datasets statistics, see Supplement Figs. S3-S6. ERA-20C is labeled as ERA20C, and ERA-20C land is labeled as ERA20CL.
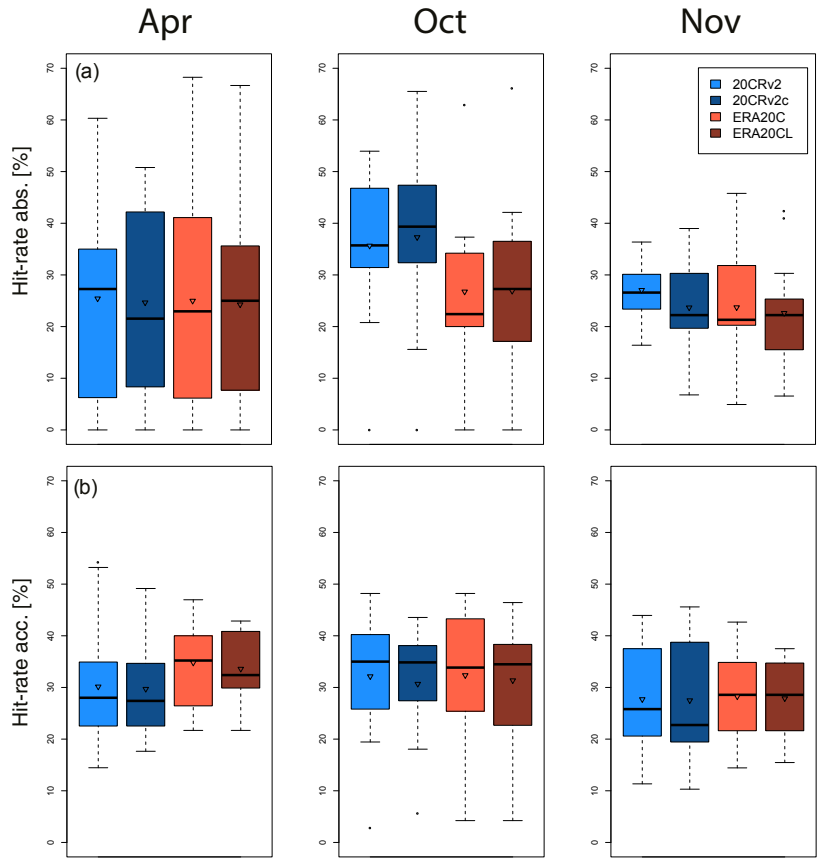

Figure 7. Boxplots graphs for the extreme events hit-rate analysis of the 13 snow depth station locations, where the triangle denotes the mean, the bold black line denotes the median, the box denotes the $25-75 \%$ percentile range (or interquartile range), the whiskers show the upper and lower end or at most the $1.5 x$ interquartile range and the dots denote outliers. (a) shows boxplots for absolute snow extreme events for the longest possible time period, and (b) is the same as (a) but for snow accumulation. Hit rates are computed for the longest period possible. ERA-20C is labeled as ERA20C, and ERA-20C land is labeled as ERA20CL. amined in this study. We found that reanalyses with less assimilated data do perform equally or better for a substantially longer time period.

Moreover, Khan et al. (2008) state that all evaluated reanalysis snow products showed the worst matching in April. The same result was found in our analysis, where April values showed the smallest correlation and highest absolute error (RMSE). Therefore, it can be assumed that models used for creating the reanalysis datasets still struggle with properly representing melting season (Slater et al., 2001). Looking at the RMSE, it could be shown that the 20CRv2 and 20CRv2c generally overestimate snow depth, and that ERA20C and ERA-20C land are closer to the station data. This is true for the recent past as for the centennial analysis. The same applies to the variability comparison. Interestingly, the snow depth RMSE in October is smaller than in the other months, but day-to-day variability (correlation) appears to be better in November. This indicates that the initial snowfall in October, if occurring, is harder to capture than in November but also generates only small snow depths. Therefore, even if completely missed by the reanalysis, it produced only small RMSEs.

Peings et al. (2013) found that 20CRv2 displays a good performance in detecting the daily advance of October and November snow (between 80 and $100 \%$ hit rate). We found that 20CRv2 shows good long-term daily correlations in October and November, even higher than ERA-20C. That said, binary snow information as well as correlation analysis masks the details of snow amount, which is better seen in anomaly or climatology maps. Moreover, our hit-rate analysis of dates for extreme snow depths and snow accumulation showed that for the 13 station locations, only about $45 \%$ of the dates were correctly computed when compared to station 
data. Among the explanations for this underwhelming performance are (a) the assimilation of only surface data in the reanalyses (which challenges the computation of the complex conditions for extreme snowfall), (b) the long time frame in which assimilated data quantity is decreasing back in time and (c) the spatial resolution of the reanalyses which can not resolve features like small-scale uplift or orographic precipitation or, at an even smaller scale, snowdrift. With these deficiencies in mind, the achieved correlation coefficients for the centennial time series are even more remarkable.

However, analysis of inter-decadal tendencies of snow depth revealed a peculiar evolution, even though snow schemes and assimilated data are comparable. Generally, the ECMWF datasets compute a stronger snow depth decrease before the 1940s than the 20CR products for the main Russian Arctic snow field. Since climatological maps do not show substantial differences, origin of the large disagreements must emerge in the pre-1950s period. The assimilated input data is nearly identical between ERA-20C and 20CRv2c, and thus model biases seem to be the source of divergence.

One reason for the snow depth evolution could be the overestimation of Arctic SLP (sea level pressure) during the pre1950s in ERA-20C (Belleflamme et al., 2015). Indeed we found that ERA-20C shows high (higher than 20CR or reconstructed values) positive SLP anomalies for the beginning of the 20th century over Central Russia (see Supplementary Fig. S7) together with a peculiar increase of atmospheric mass towards the beginning of the 20th century (not shown). Such a high pressure anomaly over the high latitudes might lead to reduced poleward moisture transport, as well as decreased cloud cover and downward long wave radiation, which is very efficient in melting snow. Moreover, stable atmospheric conditions prevent vertical motion and therefore condensation. Knudsen et al. (2015) showed that, in the recent era, Arctic anticyclonic circulation patterns also promote low snowfall in summer over the Russian sector of the Arctic, and a similar association with (too) high pressure could be at play in ERA-20C in the pre-1950s. On the other hand, if compared to station data, the ERA-20C snow depths show a good agreement for anomalies early in the 20th century.

Furthermore, near-surface temperatures influence snow depth evolution. The new $20 \mathrm{CRv} 2 \mathrm{c}$ dataset uses alternative sea ice and SST representations as boundary conditions, which improves the $2 \mathrm{~m}$ temperature performance over the Arctic compared to 20CRv2. Nevertheless, it is generally still colder than ERA-20C or CRUTEM4.4 (Climatic Research Unit Temperature version 4.4; Jones et al., 2014). However, ERA-20C is most probably much too warm during April, whereas the 20CR reanalyses seem to be too cold during November and December, thus they might be overestimating snow depths (see Supplement Figs. S8 and S9). Ultimately, there is no clear and simple answer to this issue and our anal- ysis can only provide an initial assessment of the discrepancy between the two families of reanalyses.

The results of the snow climatologies hint towards heterogeneous dataset issues. Decadal tendencies in the second half of the 20th century are better represented by the 20CR datasets (relative to their baseline), whereas tendencies for the first half of the century are better represented in ERA-20C. Unfortunately, only 13 stations could be used to verify long-term evolution in snow depth. Data recovery from a higher density network with better spatial coverage is needed to really constrain the diverging snow states in these long-term reanalyses. Moreover, future reanalysis or model comparisons might be needed. The CERA (ERA20C plus coupled ocean) reanalysis and GSWP3 (Global Soil Wetness Project phase 3) could give further insight into this topic. Model inter-comparisons concerning snow representation might reveal necessary qualities to compute a realistic snow depth.

\section{Conclusions}

Snow depth and its evolution from a variety of centennial reanalyses has been tested against in situ observations over the Russian territory. Long-term reanalyses are able to reproduce daily and sub-decadal snow depth variability very well; however, they generally overestimate snow depths. Moreover, computing the exact day of extreme snow accumulation is still a difficult task for these datasets. Spatially, the region of high and low snow and the snow cover boundaries are well represented. However, inter-decadal comparison of snow depth revealed some issues with pre-1950s snow climates over northern Russia. The ECMWF and NOAA reanalyses show diverging snow states (low or high, respectively), most likely a consequence of assimilation schemes or model biases rather than input data.

To further understand and quantify changes during the current and future Arctic warm periods, it is imperative to maintain and expand a dense network of (Arctic) snow measuring stations (including their meta data). Reproducing observed snow (depth) in climate models is a difficult challenge since many environmental factors determine snowfall amount and ultimately snow depth. In situ snow depth measurements and reanalyses are important tools to evaluate the performance of climate models.

Data availability. The NOAA-CIRES Twentieth Century Reanalysis version 2 can be downloaded at https://www.esrl.noaa.gov/ $\mathrm{psd} /$ data/gridded/data.20thC_ReanV2.html, and version 2c can be downloaded at https://www.esrl.noaa.gov/psd/data/gridded/data. 20thC_ReanV2c.html. The ECMWF reanalysis datasets can be accessed via http://apps.ecmwf.int/datasets/. The Russian in situ snow depth observations can be found at the data website of the AllRussian Research Institute of Hydrometeorological Information World Data Centre http://meteo.ru/english/data. Concerning ERA- 
20C land and ERA-Interim land-e, these are research experiments that are not available publicly but are available upon request from ECMWF without restrictions.

\section{The Supplement related to this article is available online at doi:10.5194/tc-11-923-2017-supplement.}

Competing interests. The authors declare that they have no conflict of interest.

Acknowledgements. Y. Orsolini was supported by the Norwegian Research Council (project SNOWGLACE \#244166 and EPOCASA \#229774/E10). A. Sterin and S. Brönnimann were supported by the EU-FP7 project ERA-CLIM2 (607029). M. Wegmann, Y. Orsolini, S. Brönnimann, A. Sterin and O. Bulygina acknowledge funding by the European ERAnet.RUS programme, especially within the project ACPCA. M. Wegmann also benefitted from the ARCTICERA project funded by the Agence Nationale de la Recherche (ANR) through the Belmont Fund initiative.

Edited by: M. Schneebeli

Reviewed by: T. Vihma and one anonymous referee

\section{References}

Agrawala, S.: Climate change in the European Alps: adapting winter tourism and natural hazards management, Organisation for Economic Cooperation and Development (OECD), 2007.

Balsamo, G., Albergel, C., Beljaars, A., Boussetta, S., Brun, E., Cloke, H., Dee, D., Dutra, E., Muñoz-Sabater, J., Pappenberger, F., de Rosnay, P., Stockdale, T., and Vitart, F.: ERAInterim/Land: a global land surface reanalysis data set, Hydrol. Earth Syst. Sci., 19, 389-407, doi:10.5194/hess-19-389-2015, 2015.

Barnett, T. P., Dümenil, L., Schlese, U., and Roeckner, E.: The effect of Eurasian snow cover on global climate, Science, 239, 504507, 1988

Belleflamme, A., Fettweis, X., and Erpicum, M.: Recent summer Arctic atmospheric circulation anomalies in a historical perspective, The Cryosphere, 9, 53-64, doi:10.5194/tc-9-53-2015, 2015.

Brown, R. D. and Mote, P. W.: The response of Northern Hemisphere snow cover to a changing climate, J. Climate, 22, 21242145, 2009.

Brown, R., Derksen, C., and Wang, L.: A multidata set analysis of variability and change in Arctic spring snow cover extent, 1967-2008, J. Geophys. Res.-Atmos., 115, D16111, doi:10.1029/2010JD013975, 2010.

Brown, R. D. and Robinson, D. A.: Northern Hemisphere spring snow cover variability and change over 1922-2010 including an assessment of uncertainty, The Cryosphere, 5, 219-229, doi:10.5194/tc-5-219-2011, 2011.

Brun, E., Vionnet, V., Boone, A., Decharme, B., Peings, Y., Valette, R., Karbou, F., and Morin, S.: Simulation of Northern Eurasian Local Snow Depth, Mass, and Density Using a Detailed Snow- pack Model and Meteorological Reanalyses, J. Hydrometeorol., 14, 203-219, doi:10.1175/JHM-D-12-012.1, 2013.

Bulygina, O. N., Groisman, P. Y., Razuvaev, V. N., and Radionov, V. F.: Snow cover basal ice layer changes over Northern Eurasia since 1966, Environ. Res. Lett., 5, 015004, doi:10.1088/17489326/5/1/015004, 2010.

Callaghan, T. V., Johansson, M., Prowse, T. D., Olsen, M. S., and Reiersen, L. O.: Arctic cryosphere: changes and impacts, Ambio, 40, 3-5, 2011.

Cohen, J. and Entekhabi, D.: Eurasian snow cover variability and Northern Hemisphere climate predictability, Geophys. Res. Lett., 26, 345-348, 1999.

Cohen, J. and Rind, D.: The effect of snow cover on the climate. J. Climate, 4, 689-706, 1991.

Cohen, J., Screen, J. A., Furtado, J. C., Barlow, M., Whittleston, D., Coumou, D., Francis, J., Dethloff, K., Entekhabi, D., and Overland, J.: Recent Arctic amplification and extreme mid-latitude weather, Nat. Geosci., 7, 627-637, 2014.

Compo, G. P., Whitaker, J. S., Sardeshmukh, P. D., Matsui, N., Allan, R. J., Yin, X., Gleason, B. E., Vose, R. S., Rutledge, G., Bessemoulin, P., and Brönnimann, S.: The Twentieth Century Reanalysis project, Q. J. Roy. Meteor. Soc., 137, 1-28, 2011.

Cram, T. A., Compo, G. P., Yin, X., Allan, R. J., McColl, C., Vose, R. S., Whitaker, J. S., Matsui, N., Ashcroft, L., Auchmann, R., Bessemoulin, P., Brandsma, T., Brohan, P., et al.: The international surface pressure databank version 2, Geoscience Data Journal, 2, 31-46, 2015.

Dee, D. P., Uppala, S. M., Simmons, A. J., Berrisford, P., Poli, P., Kobayashi, S., Andrae, U., Balmaseda, M. A., Balsamo, G., Bauer, P., Bechtold, P., Beljaars, A. C. M., van de Berg, L., Bidlot, J., Bormann, N., Delsol, C., Dragani, R., Fuentes, M., Geer, A. J., Haimberger, L., Healy, S. B., Hersbach, H., Hólm, E. V., Isaksen, L., Kållberg, P., Köhler, M., Matricardi, M., McNally, A. P., Monge-Sanz, B. M., Morcrette, J.-J., Park, B.-K., Peubey, C., de Rosnay, P., Tavolato, C., Thépaut, J.-N., and Vitart, F.: The ERA-interim reanalysis: Configuration and performance of the data assimilation system, Q. J. Roy. Meteor. Soc., 137, 553-597, 2011.

Dutra, E., Balsamo, G., Viterbo, P., Miranda, P. M. A., Beljaars, A., Schar, C., and Elder, K.: An improved snow scheme for the ECMWF Land Surface Model: Description and offline validation, J. Hydrometeorol., 11, 899-916, 2010.

Ek, M. B., Mitchell, K. E., Lin, Y., Rogers, E., Grunmann, P., Koren, V., Gayno, G., and Tarpley, J. D.: Implementation of Noah land surface model advances in the National Centers for Environmental Prediction operational mesoscale Eta model, J. Geophys. Res.-Atmos., 108, 8851, doi:10.1029/2002JD003296, 2003.

Flanner, M. G., Shell, K. M., Barlage, M., Perovich, D. K., and Tschudi, M. A.: Radiative forcing and albedo feedback from the Northern Hemisphere cryosphere between 1979 and 2008, Nat. Geosci., 4, 151-155, 2011.

Frei, A. and Gong, G.: Decadal to century scale trends in North American snow extent in coupled atmosphere-ocean general circulation models, Geophys. Res. Lett., 32, L18502, doi:10.1029/2005GL023394, 2005.

Frei, A., Tedesco, M., Lee, S., Foster, J., Hall, D. K., Kelly, R., and Robinson, D. A.: A review of global satellite-derived snow products, Adv. Space Res., 50, 1007-1029, 2012. 
Ghatak, D., Deser, C., Frei, A., Gong, G., Phillips, A., Robinson, D. A., and Stroeve, J.: Simulated Siberian snow cover response to observed Arctic sea ice loss, 1979-2008, J. Geophys. Res.Atmos., 117, D23108, doi:10.1029/2012JD018047, 2012.

Giese, B. S., Seidel, H. F., Compo, G. P., and Sardeshmukh, P. D.: An ensemble of historical ocean reanalyses with sparse observational input, J. Geophys. Res.-Oceans, submitted, 2016.

Hersbach, H., Peubey, C., Simmons, A., Berrisford, P., Poli, P., and Dee, D.: ERA-20CM: a twentieth-century atmospheric model ensemble, Q. J. Roy. Meteor. Soc., 41, 2350-2375, doi:10.1002/qj.2528, 2015.

Hirahara, S., Ishii, M., and Fukuda, Y.: Centennial-scale sea surface temperature analysis and its uncertainty, J. Climate, 27, 57-75, 2014.

Honda, M., Inoue, J., and Yamane, S.: Influence of low Arctic seaice minima on anomalously cold Eurasian winters, Geophys. Res. Lett., 36, L08707, doi:10.1029/2008GL037079, 2009.

Hüsler, F., Jonas, T., Riffler, M., Musial, J. P., and Wunderle, S.: A satellite-based snow cover climatology (1985-2011) for the European Alps derived from AVHRR data, The Cryosphere, 8, 73-90, doi:10.5194/tc-8-73-2014, 2014.

Jeong, J. H., Linderholm, H. W., Woo, S.-H., Folland, C., Kim, B.M., Kim, S.-J., and Chen, D.: Impact of snow initialization on subseasonal forecasts of surface air temperature for the cold season, J. Climate, 26, 1956-1972, 2013.

Jonas, T., Rixen, C., Sturm, M., and Stoeckli, V.: How alpine plant growth is linked to snow cover and climate variability, J. Geophys. Res.-Biogeo., 113, G03013, doi:10.1029/2007JG000680, 2008.

Jones, P. D., Lister, D. H., Osborn, T. J., Harpham, C., Salmon, M., and Morice, C. P.: Hemispheric and large-scale land surface air temperature variations: An extensive revision and an update to 2010, J. Geophys. Res., 117, D05127, doi:10.1029/2011JD017139, 2014.

Kanamitsu, M., Ebisuzaki, W., Woollen, J., and Shi-Keng, Y.: Ncepdoe amip-ii reanalysis (r-2), B. Am. Meteorol. Soc., 83, 1631, doi:10.1175/BAMS-83-11-1631, 2002.

Khan, V., Holko, L., Rubinstein, K., and Breiling, M.: Snow cover characteristics over the main Russian river basins as represented by reanalyses and measured data, J. Appl. Meteorol. Clim., 47, 1819-1833, 2008.

Knudsen, E. M., Orsolini, Y. J., Furevik, T., and Hodges, K. I.: Observed anomalous atmospheric patterns in summers of unusual arctic sea ice melt, J. Geophys. Res.-Atmos., 120, 2595-2611, 2015.

Koren, V., Schaake, J., Mitchell, K., Duan, Q. Y., Chen, F., and Baaker, J. M.: A parameterization of snowpack and frozen ground intended for NCEP weather and climate models, J. Geophys. Res.-Atmos., 104, 19569-19585, 1999.

Liston, G. E. and Hiemstra, C. A.: The changing cryosphere: PanArctic snow trends (1979-2009), J. Climate, 24, 5691-5712, 2011.

Onogi, K., Tsutsui, J., Koide, H., Sakamoto, M., Kobayashi, S., Hatsushika, H., Matsumoto, T., Yamazaki, N., Kamahori, H., and Takahashi, K.: The JRA-25 re-analysis, J. Meteorol. Soc. Jpn. Ser. II, 85, 369-432, 2007.

Orsolini, Y. J. and Kvamstø, N. G.: Role of Eurasian snow cover in wintertime circulation: Decadal simulations forced with satellite observations, J. Geophys. Res.-Atmos., 114, D19108, doi:10.1029/2009JD012253, 2009.

Orsolini, Y. J., Senan, R., Balsamo, G., Doblas-Reyes, F. J., Vitart, F., Weisheimer, A., Carrasco, A., and Benestad, R. E.: Impact of snow initialization on subseasonal forecasts, Clim. Dynam., 41, 1969-1982, 2013.

Peings, Y., Brun, E., Mauvais, V., and Douville, H.: How stationary is the relationship between Siberian snow and Arctic Oscillation over the 20th century?, Geophys. Res. Lett., 40, 183-188, 2013.

Peñuelas, J., Rutishauser, T., and Filella, I.: Phenology feedbacks on climate change, Science, 324, 5929, doi:10.1126/science.1173004, 2009.

Poli, P., Hersbach, H., Dee, D. P., Simmons, A. J., Vitart, F., Laloyaux, P., Tan, D. G. H., Peubey, C., Thépaut, J.-N., Trémolet, Y., Hólm, E. V., Bonavita, M., Isaksen, L., and Fisher, M.: ERA-20C: An Atmospheric Reanalysis of the Twentieth Century, J.Climate, 29, 4083-4097, 2016.

Rayner, N. A., Parker, D. E., Horton, E. B., Folland, C. K., Alexander, L. V., Rowell, D. P., Kent, E. C., and Kaplan, A.: Global analyses of sea surface temperature, sea ice, and night marine air temperature since the late nineteenth century, J. Geophys. Res.Atmos., 108, 4407, doi:10.1029/2002JD002670, 2003.

Rienecker, M. M., Suarez, M. J., Gelaro, R., Todling, R., Bacmeister, J., Liu, E., Bosilovich, M. G., Schubert, S. D., Takacs, L., and Kim, G.-K.: MERRA: NASA's modern-era retrospective analysis for research and applications, J. Climate, 24, 3624-3648, 2011.

Siljamo, N. and Hyvärinen, O.: New geostationary satellite-based snow-cover algorithm, J. Appl. Meteorol. Clim., 50, 1275-1290, 2011.

Slater, A. G., Schlosser, C. A., Desborough, C. E., Pitman, A., Henderson-Sellers, A., Robock, A., Vinnikov, K. Y., Mitchell, K., Boone, A., Braden, H., Chen, F., Cox, P. M., De Rosnay, P., Dickinson, R. E., Dai, Y., Duan, Q., Entin, J., Etchevers, P., Gedney, N., Gusev, Y. M., Habets, F., Kim, J., Koren, V., Kowalczyk, E., Nasonova, O. N., Noilhan, J., Schaake, J., Shmakin, A. B., Smirnova, T. G., Verseghy, D., Wetzel, P., Xue, Y., Yang, Z.L., and Zeng, Q.-C.: The representation of snow in land surface schemes: Results from pilps 2 (d), J. Hydrometeorol., 2, 7-25, 2001.

Uppala, S. M., Kållberg, P. W., Simmons, A. J., Andrae, U., Bechtold, V., Fiorino, M., Gibson, J. K., Haseler, J., Hernandez, A., and Kelly, G. A.: The ERA-40 reanalysis, Q. J. Roy. Meteor. Soc., 131, 2961-3012, 2005.

Wegmann, M., Orsolini, Y., Vázquez, M., Gimeno, L., Nieto, R., Bulygina, O., Jaiser, R., Handorf, D., Rinke, A., and Dethloff, K.: Arctic moisture source for Eurasian snow cover variations in autumn, Environ. Res. Lett., 10, 054015, doi:10.1088/17489326/10/5/054015, 2015.

Wu, R., Liu, G., and Ping, Z.: Contrasting Eurasian spring and summer climate anomalies associated with western and eastern Eurasian spring snow cover changes, J. Geophys. Res.-Atmos., 119, 7410-7424, 2014.

Yasunari, T., Kitoh, A., and Tokioka, T.: Local and remote responses to excessive snow mass over Eurasia appearing in the northern spring and summer climate - a study with the MRI GCM, J. Meteorol. Soc. Jpn., 4, 473-487, 1991.

Ye, K., Wu, R., and Liu, Y.: Interdecadal change of Eurasian snow, surface temperature, and atmospheric circulation in the late 1980s, J. Geophys. Res.-Atmos., 120, 2738-2753, 2015. 
Zhang, X., He, J., Zhang, J., Polyakov, I., Gerdes, R. U. D., Inoue, J., and Wu, P.: Enhanced poleward moisture transport and amplified northern high-latitude wetting trend, Nature Climate Change, 3, 47-51, 2013.
Zuo, Z., Yang, S., Zhang, R., Xiao, D., Guo, D., and Ma, L.: Response of summer rainfall over China to spring snow anomalies over Siberia in the NCEP CFSv2 reforecast, Q. J. Roy. Meteor. Soc., 141, 939-944, 2015. 